\title{
Grey Wastewaters: Treatment and Potential Reuse in an Arid Climate
}

\author{
Ali Mekki*, Firas Feki, Mariem Kchaou, Sami Sayadi \\ Laboratory of Bioprocesses, Center of Biotechnology of Sfax, AUF (PER-LBP), Sfax, Tunisia \\ Email: *a_mekki_cbs@yahoo.fr
}

Received 5 April 2015; accepted 12 May 2015; published 15 May 2015

Copyright (C) 2015 by authors and Scientific Research Publishing Inc.

This work is licensed under the Creative Commons Attribution International License (CC BY). http://creativecommons.org/licenses/by/4.0/

c) (i) Open Access

\begin{abstract}
We investigated the effects of treated grey wastewaters on soil properties, on seeds germination and on plants growth. The application of these wastewaters for irrigation of the soil and plants gave significant results. Indeed we noticed improvement of soil water retention capacity (SWRC) by an average of $12 \%$, soil organic matter content (SOM) which increases by $30 \%$ and enhancement in soil microflora count by $\mathbf{8 0} \%$. Besides, the germination indexes of Tomato (Lycopersicon esculentum) and Alfalfa (Medicago sativa) were increased by an average of $30 \%$ and $50 \%$ respectively in soil irrigated by untreated and treated grey wastewaters. Moreover, better growth levels for tested plant species-Wheat (Triticum durum), Barley (Hordeum vulgare) and Sorghum (Sorghum bicolor) were obtained in presence of treated wastewaters.
\end{abstract}

\section{Keywords}

Grey Waste Waters, Bioreactor, Soil, Germination, Plants

\section{Introduction}

The increasing water scarcity worldwide along with rapid increase of population in urban areas gives rise to concern about appropriate water management practices. Accordingly, wastewaters treatment is now receiving greater attention from the World Bank and government's regulatory bodies [1].

The use of wastewaters for irrigation is well established in arid and semiarid areas around the world [2]. The main advantage of wastewaters irrigation, in addition to the implied nutrient input, is the constant availability of this water resource [3] [4].

However, as wastes are products of human society, enhanced concentrations of potential toxic substances including trace metals are generally found in wastewaters, which may limit the long-term use of effluents for

\footnotetext{
"Corresponding author.
}

How to cite this paper: Mekki, A., Feki, F., Kchaou, M. and Sayadi, S. (2015) Grey Wastewaters: Treatment and Potential Reuse in an Arid Climate. Journal of Water Resource and Protection, 7, 561-571. 
agricultural purposes [5] [6]. Another problem of wastewaters disposal on agricultural land is the potentially phytotoxic nature of organic compounds or low molecular weight fatty acids, which may inhibit seeds germination [7] [8].

Mediterranean soils under semiarid and arid conditions are prone to losing organic matter [9]. The vegetation cover is very sparse leading to low inputs of organic matter into the soil [10] [11].

Treated wastewaters can have direct effects on soil chemical parameters. It can modify the minerals, macroand micronutrients for plants growth, soil pH, soil buffer capacity, and cations exchange capacity [12], but can also have a negative impact, leading to the accumulation of heavy metals or increased soil salinity if the electrical conductivity is relatively high [13]. Therefore, it is necessary to precisely know the composition of waters before applying it to the soil to guarantee minimal impact in terms of contamination and salinization [14].

Our objective in this study was to investigate the potential opportunity of use of treated grey waters as an irrigation source. We compare short-term effects of untreated and treated grey waters on several soil properties and crops germination and growth.

\section{Materials and Methods}

\subsection{Grey Wastewaters Origin and Sampling}

Grey wastewaters were obtained from different origins (Sfax-Tunisia). They represent an homogenous mixture collected from the kitchen (50\%), from the shower (25\%) and from the landery (25\%). The characteristics of these wastewaters were presented in Table 1.

\subsection{Bioreactor Description}

The reactor, which is the subject of this study, is an aerobic fixed-bed bioreactor. This reactor is planned in the Laboratory of Environmental Bioprocesses (LBPE) at the Center of Biotechnology of Sfax (CBS), Tunisia.

Table 1. Physicochemical and microbiological characteristics of untreated and treated grey waters (averages values).

\begin{tabular}{|c|c|c|}
\hline Parameters & UWW (Influent) & TWW (STF Effluent) \\
\hline $\mathrm{pH}\left(25^{\circ} \mathrm{C}\right)$ & $6.8 \pm 0.2$ & $7.6 \pm 0.2$ \\
\hline $\mathrm{EC}\left(\mathrm{mS} \cdot \mathrm{cm}^{-1}\right)$ & $2.6 \pm 0.1$ & $2.9 \pm 0.1$ \\
\hline $\operatorname{TSS}\left(g \cdot L^{-1}\right)$ & $0.32 \pm 0.02$ & $0.15 \pm 0.01$ \\
\hline $\mathrm{COD}\left(\mathrm{mg} \cdot \mathrm{L}^{-1}\right)$ & $1441 \pm 45$ & $95 \pm 5$ \\
\hline $\mathrm{BOD}_{5}\left(\mathrm{mg} \cdot \mathrm{L}^{-1}\right)$ & $850 \pm 25$ & $75 \pm 3$ \\
\hline $\mathrm{COD} / \mathrm{BOD}_{5}$ & $1.7 \pm 0.02$ & $2.8 \pm 0.05$ \\
\hline TOC $\left(\mathrm{mg} \cdot \mathrm{L}^{-1}\right)$ & $480 \pm 12$ & $62 \pm 3$ \\
\hline TKN (mg $\left.\cdot \mathrm{L}^{-1}\right)$ & $74.3 \pm 3$ & $37 \pm 2$ \\
\hline $\mathrm{NO}_{3}\left(\mathrm{mg} \cdot \mathrm{L}^{-1}\right)$ & $0.6 \pm 0.1$ & $0.7 \pm 0.1$ \\
\hline $\mathrm{NO}_{2}\left(\mathrm{mg} \cdot \mathrm{L}^{-1}\right)$ & ND & $0.04 \pm 0.01$ \\
\hline P (\%) & $0.1 \pm 0.01$ & $0.08 \pm 0.01$ \\
\hline Сa (\%) & $0.12 \pm 0.01$ & $0.1 \pm 0.01$ \\
\hline $\mathrm{K}(\%)$ & $0.34 \pm 0.04$ & $0.32 \pm 0.04$ \\
\hline $\mathrm{Na}(\%)$ & $1.6 \pm 0.1$ & $1.8 \pm 0.1$ \\
\hline $\operatorname{Mg}(\%)$ & ND & ND \\
\hline Total aerobic germs $\left(10^{4}\right.$ UFC $\left.100 \mathrm{~mL}^{-1}\right)$ & $14.7 \pm 2$ & $0.005 \pm 0.001$ \\
\hline Salmonella & ND & ND \\
\hline Staphylococcus & ND & ND \\
\hline Pseudomonas & ND & ND \\
\hline
\end{tabular}

UWW: untreated grey waters; TWW: treated grey waters; STF: septic tank filter; ND: not detected. 
The aerobic biological filter is one liter working volume filled with plastic media with specific surface area of $80 \mathrm{~m}^{2} \cdot \mathrm{m}^{-3}$. The filter is occupied in the top with a perforated nozzle for uniform water distribution. Wastewaters were lifted for distribution by mini-pump. As a second step, and by the level the treated grey waters were filtered in anoxic bed reactor using volcanic rock and sand filter. The sand filter is composed by two layers; a gravel layer in the bottom and sand layer in the top. The treated effluent was characterized and tested for soil and plant irrigation

\subsection{Grey Wastewaters Physico-Chemical Analyses}

The $\mathrm{pH}$ and the electrical conductivity (EC) were determined according to standard method [15]. Organic matter (OM) was determined by combustion of the samples in a furnace at $550^{\circ} \mathrm{C}$ for $4 \mathrm{~h}$. Total organic carbon was determined by dry combustion. Total nitrogen was determined according to [16]. Chemical oxygen demand (COD) was determined according to [17]. Five-day biochemical oxygen demand $\left(\mathrm{BOD}_{5}\right)$ was determined by the manometric method with a respirometer. Phosphorus, magnesium, potassium, calcium and sodium were determined by atomic absorption.

\subsection{Grey Wastewaters Microbiological Analyses}

Total mesopholic microfloras were counted according to [18]. The identification and enumeration of Salmonella were carried out according to [19]. Staphylococcus and Pseudomonas were identified and enumerated according to [20].

\subsection{Soil Origin and Description}

The studied soil located in the region of “El Ain” Sfax-Tunisia (North latitude $34^{\circ} 3$ ', East longitude $10^{\circ} 20^{\prime}$, the mean annual rainfall is $200 \mathrm{~mm}$ ). It is a sandy soil in surface and depth, with a basic pH (8.9), a low EC (298 $\mu \mathrm{S}$ $\left.\mathrm{cm}^{-1}\right)$ and is poor in organic matter content $\left(1.7 \mathrm{~g} \cdot \mathrm{kg}^{-1}\right.$ dry soil). The nitrogen, potassium and phosphorus were very low (view Table 2). Soil samples were collected from an uncultivated plot, analyzed (for physico-chemical analyses) and immediately stored at $-4^{\circ} \mathrm{C}$ for microbiological analyses.

\subsection{Soil Physicochemical Analyses}

The $\mathrm{pH}$ and EC of each sample (soil and wastewaters/soil mixtures) were determined according to [21]. $\mathrm{pH}$ values were measured using a pH meter Mettler Toledo MP 220. EC values were measured by a conductivity meter CONSORT.

Samples dry matters, water contents, organic matter (OM) and inorganic matter were determined according to [15]. For the determination of total nitrogen, the method of [18] has been applied.

\subsection{Soil Microbiological Analyses}

Ten grams of each sample (control soil, wastewaters/soil mixtures) was suspended in an Erlenmeyer flask containing $90 \mathrm{ml}$ of a sterile solution $\left(0.2 \%\right.$ of sodium polyphosphate $\left(\mathrm{NaPO}_{3}\right) \mathrm{n}$ in distilled water, $\left.\mathrm{pH} 7.0\right)$ and $10 \mathrm{~g}$ of sterile glass beads (1.5 mm diameter). The flask was shaken at $200 \mathrm{rpm}$ for $2 \mathrm{~h}$. Serial 10-fold dilutions of the samples in a $0.85 \% \mathrm{NaCl}$ solution were plated in triplicate on PCA at $30^{\circ} \mathrm{C}$ for total bacterial counts, on sabouraud containing chloramphenicol at $25^{\circ} \mathrm{C}$ for fungi (yeasts and moulds), on DCL at $37^{\circ} \mathrm{C}$ for total coliforms. For spore-forming bacteria counts, aliquots were heated for $10 \mathrm{~min}$ at $80^{\circ} \mathrm{C}$ before spreading on PCA and incubation at $37^{\circ} \mathrm{C}$.

Each sample was analyzed in duplicate and the dilution series were plated in triplicate for each medium. All these counts were expressed as colony forming units (CFU) per gram of dried soil $\left(24 \mathrm{~h}\right.$ at $\left.105^{\circ} \mathrm{C}\right)$.

\subsection{Agronomic Valorization Tests of Untreated and Treated Grey Wastewaters}

Effects of untreated grey wastewaters, treated grey wastewaters and wastewaters/soil mixtures on seeds germination of two standard plants species: Tomato (Lycopersicon esculentum) and Alfalfa (Medicago sativa) were assessed by determination of the germination index according to [22]. Moreover, effects of untreated and treated grey wastewaters on growth of three cultivated plants species; Wheat (Triticum durum), Barley (Hordeum vul- 
Table 2. Physicochemical characteristics of mixtures UWW/soil and TWW/soil in comparison with control soil (CS) (averages values in air-dried soils after 60 days incubation).

\begin{tabular}{cccc}
\hline Parameters & $\mathrm{CS}$ & UWW/soil & TWW/soil \\
\hline $\mathrm{pH}$ & $8.9 \pm 0.2$ & $8.3 \pm 0.2$ & $8.6 \pm 0.2$ \\
$\mathrm{EC}\left(\mu \mathrm{S} \cdot \mathrm{cm}^{-1}\right)$ & $298 \pm 14$ & $620 \pm 20$ & $690 \pm 20$ \\
Dry matter $\left(\mathrm{g} \cdot \mathrm{Kg}^{-1}\right)$ & $91.92 \pm 5$ & $90.7 \pm 5$ & $90.9 \pm 5$ \\
Water content $\left(\mathrm{g} \cdot \mathrm{Kg}^{-1}\right)$ & $8.07 \pm 0.4$ & $9.3 \pm 0.5$ & $9.1 \pm 0.5$ \\
Organic matter $\left(\mathrm{g} \cdot \mathrm{Kg}^{-1}\right)$ & $1.7 \pm 0.08$ & $2.5 \pm 0.1$ & $2.2 \pm 0.1$ \\
$\mathrm{TKN}\left(\mathrm{mg} \cdot \mathrm{Kg}^{-1} \mathrm{dry}\right.$ matter$)$ & $0.12 \pm 0.03$ & $0.2 \pm 0.01$ & $0.16 \pm 0.01$ \\
$\mathrm{~N}-\mathrm{NH}\left(\mathrm{mg} \cdot \mathrm{Kg}{ }^{-1} \mathrm{dry} \mathrm{matter}\right)$ & $0.03 \pm 0.01$ & $0.06 \pm 0.02$ & $0.05 \pm 0.01$ \\
$\mathrm{TOC}\left(\mathrm{mg} \cdot \mathrm{Kg}{ }^{-1} \mathrm{dry}\right.$ matter$)$ & $1.45 \pm 0.07$ & $2.1 \pm 0.1$ & $1.8 \pm 0.1$ \\
$\mathrm{C} / \mathrm{N}$ & $13 \pm 0.6$ & $11 \pm 0.5$ & $11.3 \pm 0.5$ \\
$\mathrm{P}(\%)$ & $0.4 \pm 0.02$ & $1.2 \pm 0.05$ & $1 \pm 0.05$ \\
$\mathrm{Ca}(\%)$ & $0.9 \pm 0.04$ & $1.4 \pm 0.07$ & $1.2 \pm 0.06$ \\
$\mathrm{~K}(\%)$ & $1.03 \pm 0.05$ & $1.45 \pm 0.07$ & $1.3 \pm 0.06$ \\
$\mathrm{Na}(\%)$ & $1.02 \pm 0.05$ & $2.4 \pm 0.1$ & $2.7 \pm 0.1$ \\
$\mathrm{Mg}(\%)$ & $0.7 \pm 0.03$ & $1.1 \pm 0.05$ & $0.8 \pm 0.04$ \\
Sand (\%) & $71.84 \pm 3$ & $70.45 \pm 3$ & $71.2 \pm 3$ \\
$\mathrm{Clay}(\%)$ & $21.16 \pm 1$ & $23 \pm 1$ & $21.2 \pm 1$ \\
Silt (\%) & $7 \pm 0.5$ & $6.55 \pm 0.5$ & $7.6 \pm 0.5$ \\
\hline
\end{tabular}

gare) and Sorghum (Sorghum bicolor) were investigated in ambient conditions.

\subsection{Statistical Analyses}

For physicochemical analyses, three replications were used for each parameter. For microbiological analyses, each sample was analyzed in duplicate, and the dilution series were plated in triplicate for each medium. Data were analyzed using the ANOVA procedure. Variance and standard deviation were determined using Genstat 5 (second edition for windows).

\section{Results}

\subsection{Grey Wastewaters Physicochemical Parameters Evolution}

The optimum $\mathrm{pH}$ for the treatment of wastewaters by an aerobic process is between 6 and 8.5. Based on the results presented in Table 1, it can be noted that the $\mathrm{pH}$ in the bioreactor was in the right range and varies between 7.3 and 7.8.

The EC of the effluent was higher than the influent one; this can be explained by organic matter mineralization and evaporation of a certain volume of water in the bioreactor since working under aerobic conditions.

The levels of total organic carbon (TOC) at the entrance of the bioreactor fluctuate between 124 and 157 $\mathrm{mg} \cdot \mathrm{L}^{-1}$. After the various stages of treatment, there was a significant decrease in these concentrations. Indeed, the residual concentration at the outlet of the bioreactor does not exceed $62 \mathrm{mg} \cdot \mathrm{L}^{-1}$.

Analyses of $\mathrm{BOD}_{5}$ and total nitrogen were made for eight samples during treatment period. The values of $\mathrm{BOD}_{5}$ at the entrance of the bioreactor were almost constant since they vary between 800 and $900 \mathrm{mg} \cdot \mathrm{L}^{-1}$ (Table 1). After treatment, a large amount of this pollution was eliminated. The residual concentration at the outlet of the bioreactor varies between 50 and $100 \mathrm{mg} \cdot \mathrm{L}^{-1}$.

The concentration of nitrogen input was variable, it fluctuates between 53.9 and $94.7 \mathrm{TKN} \mathrm{mg} \cdot \mathrm{L}^{-1}$ (Table 1). In addition, the elimination of nitrogen pollution was achieved through an anoxic zone downstream of aerobic fixed bed reactor (at the septic tank) which is favorable to denitrification process. The concentrations of nitrogen 
remaining in the treated waters ranged from 23.8 to $51.8 \mathrm{TKN} \mathrm{mg} \cdot \mathrm{L}^{-1}$ (Table 1 ).

\subsection{Grey Wastewaters Microbiological Characteristics}

Microbiological analyzes were performed for all samples and were focused on the detection and enumeration of total aerobic bacteria, Salmonella, Staphylococcus and Pseudomonas.

The total count of aerobic microorganisms inform on the microbiology of the bioreactor in general. The density of these microorganisms was between $6.2 \times 10^{4}$ and $23 \times 10^{4} \mathrm{CFU} 100 \mathrm{~mL}^{-1}$ in the reactor entrance. These microorganisms were weakly detected in the treated waters with very low and irrelevant count ranging from 34 to $59 \mathrm{CFU} 100 \mathrm{~mL}^{-1}$ (Table 1). Concerning Salmonella, Staphylococcus and Pseudomonas, our results show that treated grey waters were exempt from these pathogenic germs.

\subsection{Grey Wastewaters Effects on Soil Physicochemical Properties}

The evolution of soil pH after irrigation with untreated (UWW) and treated (TWW) grey waters was followed for 60 days under ambient conditions.

The $\mathrm{pH}$ values of different samples were very close to those values of the control soil. Thus, small changes in $\mathrm{pH}$ were observed for UWW/soil and TWW/soil mixtures compared to the control soil that was slightly alkaline. TWW/soil mixture shows a remarkable $\mathrm{pH}$ decrease from 8.7 to 8.4 after 40 days of incubation and this value increases again until it reaches the initial control soil $\mathrm{pH}$ value. It should be noted that the optimum soil $\mathrm{pH}$ is between 6 and 7 and the majority of nutrients are assimilated by plants in this $\mathrm{pH}$ range. Similarly, soils with a $\mathrm{pH}$ of around 8 are usually still very productive and have good nutrient uptake (Table 2).

Monitoring the dissolved salt content by measuring the electrical conductivity in the different samples shows that the EC values increase going from TWW/soil mixture during the third (final) biological treatment step. However, the EC values were all below the inhibitory value (estimated at $2 \mathrm{mS} \cdot \mathrm{cm}^{-1}$ ) for sensitive crops (Table 2).

Water plays an important role, it is primarily a fundamental factor in soil formation and evolution and it is considered as a vector of nutrients and an essential element for plant life.

The monitoring of soil water retention capacity shows an increase in UWW/soil and TWW/soil mixtures in comparison to control soil. Indeed, the SWRC increases from $8.7 \%$ to $9.8 \%$ at the end of the experiment in TWW/soil mixture (Table 2).

Table 2 shows that SOM raised from $1.75 \%$ to $2.5 \%$ in the UWW/soil mixture at the end of the incubation. This can be explained by the richness of the raw grey waters in organic matter in comparison with the treated waters.

The evolution of TOC was followed throughout the incubation period. The results indicate a TOC decrease in the UWW/soil mixture during incubation. This can be explained by the mineralization of organic matter and the loss of carbon in volatile acids.

Total Kjeldhal nitrogen (TKN) content was increased especially in soil irrigated with UWW compared to the

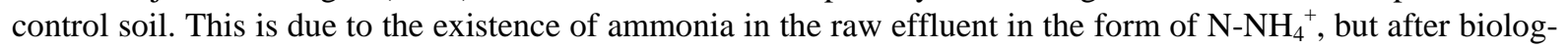
ical treatment, the treated waters has low nitrogen levels.

The average total phosphorus (P) content of successive samples of control soil was $0.4 \%$. Soil phosphorus content increased after addition of UWW (1.2\%) and in lower level with TWW (1\%) after 60 days of incubation (Table 2).

The content of soil potassium (K) differs from the mineralogical composition of the rock and the intensity of losses by export by leaching and/or erosion. The potassium content in the UWW/soil mixture was greater than the control soil (Table 2).

\subsection{Grey Wastewaters Effects on Soil Microbiological Properties}

The microorganisms influence differently the structure and biological activity of the soil according to their types, their metabolism and their synthetic products.

The total mesophilic microflora enumerated in the control soil was relatively low (3.12 $\times 10^{3} \mathrm{CFU} \mathrm{g}^{-1}$ dry soil). This may be due to the exceptional organic matter deficiency in Tunisians soils and the arid climate. During the incubation period, there has been a rise in the total number of germs witch increases to $5.5 \times 10^{3} \mathrm{CFU} \mathrm{g}^{-1}$ 
dry soil and to $8.57 \times 10^{3} \mathrm{CFU} \mathrm{g}^{-1}$ dry soil, with TWW and UWW respectively. This increase in mesophilic aerobic microflora could be explained by environmental enrichment in mineral nitrogen available to aerobic bacteria that are also active after irrigation and raw water soluble carbon also provided.

The enumeration of fungi (yeasts and moulds) show a remarkable increase with UWW $\left(8 \times 10^{2} \mathrm{CFU} \mathrm{g}^{-1}\right.$ dry soil) compared to the control soil $\left(4.5 \times 10^{2} \mathrm{CFU} \mathrm{g}^{-1}\right.$ dry soil). This could be explained by the fact that yeasts and moulds were more adapted to acidic conditions. Indeed, the richness of UWW in acidic compounds was favorable for the development of these germs. We also note the existence of these germs in the soil irrigated by TWW but with a lower number $\left(3.8 \times 10^{2} \mathrm{CFU} \mathrm{g}^{-1}\right.$ dry soil). The number of spore-forming bacteria in the control soil was about $2.8 \times 10^{2} \mathrm{CFU} \mathrm{g}^{-1}$ dry soil. As for other types of microorganisms, there was an increase of these bacteria in the UWW/soil mixture $\left(5.5 \times 10^{2} \mathrm{CFU} \mathrm{g}^{-1}\right.$ dry soil), followed by a decrease in the TWW/soil mixture $\left(2.3 \times 10^{2} \mathrm{CFU} \mathrm{g}^{-1}\right.$ dry soil). The enumeration of coliforms indicates the absence of such germs also in control soil and in waters/soil mixtures (Figure 1).

\subsection{Grey Wastewaters Effects on Seeds Germination and on Plants Growth}

To assess the phytotoxicity of the untreated and treated wastewaters, germination tests were carried out. The evolution of germination index (GI) of Tomato and Alfalfa seeds over time in the presence of raw and treated wastewaters was followed on samples of $0,15,30$ and 45 days soil incubation. Seeds germination was evaluated in comparison with a control irrigated with distilled water (Figures 2(a)-(b)).

The illustration of the GI evolution of Alfalfa and Tomato shows that GI has gradually increased over time for raw and treated grey waters. Then, for Tomato seeds, the GI reaches $140 \%$ and $170 \%$ respectively in UWW/soil and TWW/soil mixtures, after 45 days incubation. Same results were obtained with Alfalfa seeds, whose GI reaches $110 \%$ and $125 \%$, respectively in UWW/soil and TWW/soil mixtures.

Grey waters effects on plants growth; Wheat (Triticum durum), Barley (Hordeum vulgare) and Sorghum (Sorghum bicolor) were investigated.

For Wheat, the levels of plants growth obtained show a slope after 60 days of incubation including UWW substrate. This slope was not observed in the case of control soil where the evolution of the size of Wheat plants essentially follows a straight low slope. At the end of the growth cycle, the final plants height stabilizes at $31 \mathrm{~cm}$, $48 \mathrm{~cm}$ and $51 \mathrm{~cm}$ in control soil, UWW/soil and TWW/soil mixtures respectively (Figure 3(a)).

Regarding Barley plants, we note that at the beginning of the experiment, the growth was superior with raw and treated grey waters. In fact, after 60 days, we note that the plants height stabilizes at $32 \mathrm{~cm}$ in the control soil, whereas in the presence of UWW and TWW stabilizes at average heights of 45 and $47 \mathrm{~cm}$ respectively (Figure 3(b)). The positive effects were similar in Sorghum plants whose growth levels show more pronounced plants after 60 days with maximum plants height of $55 \mathrm{~cm}$ and $62 \mathrm{~cm}$ with UWW and TWW respectively (Figure 3(c)).

The number of leaves is proportional to the size of the plant as well as the length of the plant root. Generally these parameters are influenced by water stress and lack of nutrients. Indeed, we reported that a level change in

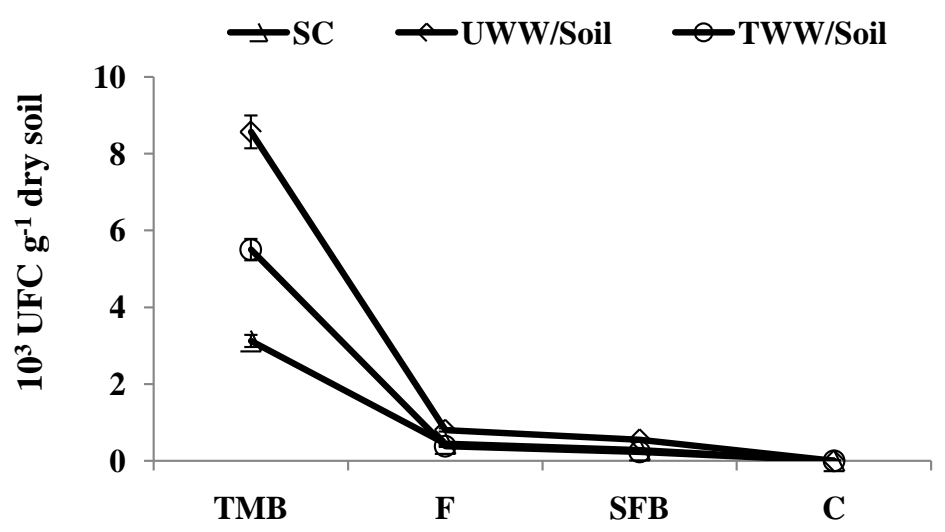

Figure 1. Effects of grey waters on soil microflora (TMB: total mesophilic bacteria; F: fungi (yeasts and moulds); SFB: spore forming bacteria; C: coliforms). 


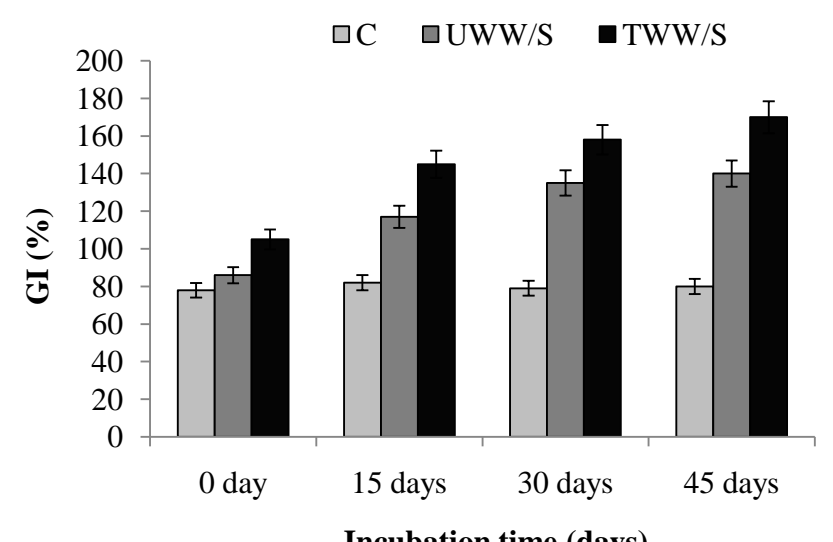

(a)

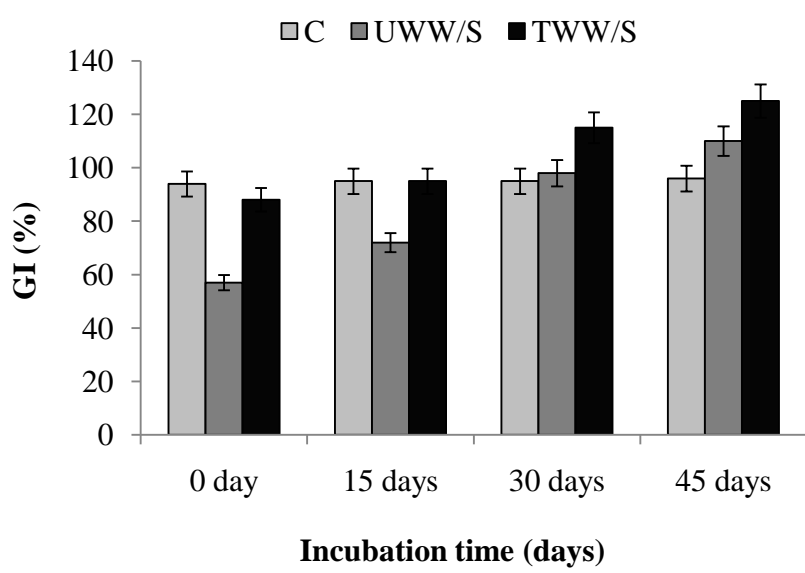

(b)

Figure 2. (a) Tomato (Lycopersicon esculentum) GIs (\%) as a function of time in presence of wastewaters/soil mixtures and in comparison with control medium (C); (b) Alfalfa (Medicago sativa) GIs (\%) as a function of time in presence of wastewaters/soil mixtures and in comparison with control medium (C).

the number of leaves similar to changes in plant height for the three tested species. In addition, we noticed the positive effect of the raw and treated grey waters on the growth of these plants species other than the brightly colored plants reflecting increased availability of nitrogen (main actor of chlorophyll synthesis).

In wheat specie, the total plant fresh weight that pushed in the presence of raw and treated grey waters was on average $1.46 \mathrm{~g}$ and $2.56 \mathrm{~g}$ respectively, while it does not exceed $0.51 \mathrm{~g}$ for control soil. For barley, and as discussed above, a significant increase in fresh weight was observed. Then, barley fresh weight increases from an average of $0.67 \mathrm{~g}$ in the control soil, to an average of $1.58 \mathrm{~g}$ and $2.31 \mathrm{~g}$, in soil irrigated with untreated and treated waters respectively. These results have been proven in sorghum with improved fresh weight, dry weight and fresh weight/dry weight ratios in UWW/ soil and TWW/soil mixtures (data not shown).

\section{Discussion}

With increasing population and economic growth, treatment and safe disposal of wastewaters is essential to preserve public health and reduce intolerable levels of environmental degradation. In addition, adequate wastewaters management is also required for preventing contamination of water bodies for the purpose of preserving the sources of clean water.

In Mediterranean areas, the current accessibility to groundwater is low because of overexploitation of aquifers. Moreover, the quality of the available water is deteriorating [23], and there is a need to find alternatives to satisfy 


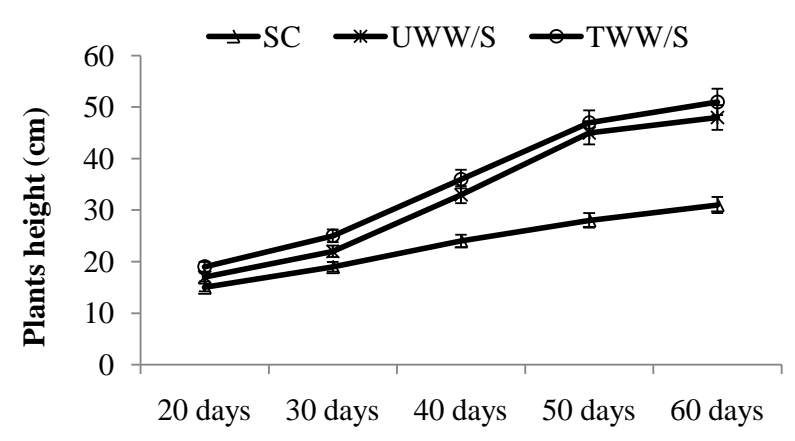

Incubation time (days)

(a)

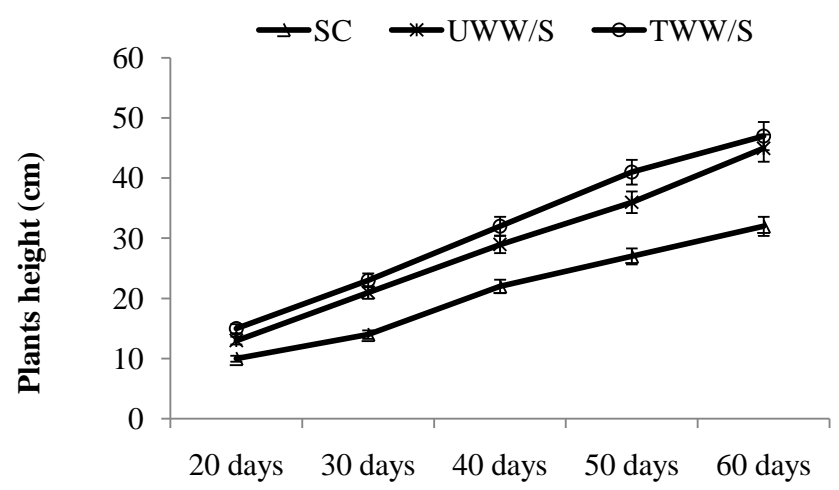

Incubation time (days)

(b)

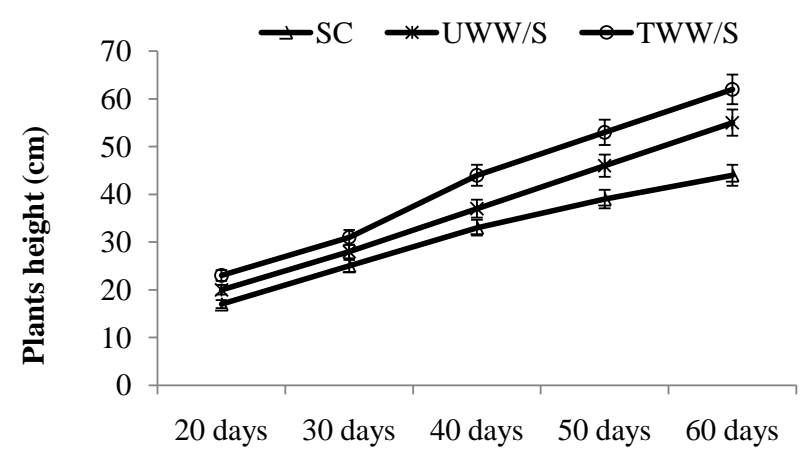

Incubation time (days)

(c)

Figure 3. (a) Wheat plants growth evolution as a function of time in presence of wastewaters/soil mixtures and in comparison with soil control (SC); (b) Barley plants growth evolution as a function of time in presence of wastewaters/soil mixtures and in comparison with soil control (SC); (c) Sorghum plants growth evolution as a function of time in presence of wastewaters/soil mixtures and in comparison with soil control (SC).

this strong demand.

The treatment of urban wastewaters has been significant progress with the development of submerged biofiltration technology. Indeed, compared to conventional treatment methods, aerobic fixed-bed bioreactor has several advantages. It requires less space, provides high quality treated waters and allows better control of biological conditions [24]. 
Our main objective in this work was to apply the technique of aerobic fixed bed reactor for the treatment of grey waters. This treatment was carried out in three successive stages. During the first stage of biological treatment, there is a $75 \%$ reduction of COD after 43 days of continuous treatment. During the second treatment period, the reduction of COD reaches $80 \%$ and after optimization of operational conditions (in the third treatment stage), the COD removal efficiency reached $84 \%$.

Treated waters exhibit physicochemical and microbiological qualities. Then, based on our results, treated waters $\mathrm{pH}$ is in the right range and varies between 7.3 and 7.8, and these waters were exempt from pathogenic germs as Salmonella, Staphylococcus and Pseudomonas. That meet the required standards of World Health Organization (WHO) hat require microbiological pollution of used wastewaters must remain below 1000 coliforms $100 \mathrm{~mL}^{-1}$ and 1 helminthe $\mathrm{L}^{-1}[25]$.

The best way to use treated wastewaters is in the irrigation of soils, which can relieve a great deal of pressure on fresh water resources [26]. Subsequently, in a second part of our work, we tried to evaluate the effects of the raw and treated grey wastewaters in soil and plants.

Our results found that wastewaters (raw and treated) does not lead to large changes in soil $\mathrm{pH}$ compared to control soil and stabilize at around 8 after 60 days of incubation. These $\mathrm{pH}$ levels provide a good nutrient uptake by plants. According to [26], an acidic soil pH leads to a decrease of $18 \%$ of the microbial biomass. Such an observed increase in soil $\mathrm{pH}$, following treated wastewaters irrigation, concurs with the findings of other authors [27].

For the electrical conductivity, the contribution of raw or treated wastewaters increased soil salinity due to mineralization of organic constituents. This can be explained by the increase of the salts concentration that is due to organic matter mineralization and the evaporation of a certain volume of water within the reactor. However, the EC values were all below the inhibitory value (estimated at $2 \mathrm{mS} \cdot \mathrm{cm}^{-1}$ ) for sensitive crops [28]. According to [29], organic fertilization contributes to the development of land affected by salinity.

The increase of soil water retention capacity is explained by the affinity of the organic matter to water (hydrophilic organic matter). [30] reported that the incorporation of organic matter in the soil increases the amount of retained water up to $30 \%$.

The phosphorus (Pt) content increases with UWW after 60 days of incubation. Thus, from an agronomic point of view, increasing the phosphorus content of the soil enhances the availability of phosphate ions to the plant [31].

The content of soil potassium (K) differs from the mineralogical composition of the rock and the intensity of losses by export by leaching and/or erosion [32]. The potassium content increases with UWW and TWW than the control soil. This increase in potassium content can be explained by the binding of $\mathrm{K}^{+}$ions from the mineralization of organic matter in the absorbing complex and decreased by the decrease in the cation exchange capacity by the degradation of organic matter [33].

The microorganisms influence differently the structure and biological activity of the soil according to their types, their metabolism and their synthetic products [34]. Fungi have the ability to bind soil particles via several mechanisms (mechanical retention, adhesion by fungal glues...). Previous studies, concerning soils under longterm irrigation with untreated wastewaters, have reported an increase in soil microflora which can be attributed to the high contents of organic compounds in the applied wastewaters [32] [35].

Moreover, the best germination indexes and crops growth were observed for UWW/soil and TWW/soil mixtures in comparison with control soil. In this way, many authors established that organic matter addition influences not only the soil physical properties, but also microbial activities and availability of plant nutrients [36]. In line with this, [37] showed that organic residue incorporation enhances soil sustainability, water movement and crops production.

\section{Conclusions}

The uncontrolled disposal to the environment of municipal, industrial and agricultural liquid, solid, and gaseous wastes constitutes one of the most serious threats to the sustainability of human civilization by contaminating the water, land, and air and by contributing to global warming.

The treatment of urban wastewaters has been significant progress with the development of submerged biofiltration technology.

Grey waters treated by fixed-bed bioreactor exhibit physicochemical and microbiological qualities that meet 
the required standards for reuse in irrigation. Indeed, the COD removal efficiency reached $84 \%$; the $\mathrm{BOD}_{5}$ removal efficiency reached $91 \%$ and the treated waters $\mathrm{pH}$ was in the right range. Moreover, treated waters were exempt from pathogenic germs as Salmonella, Staphylococcus and Pseudomonas.

Our results found several variations in the soil properties as a result of irrigation with treated wastewaters. There was steadiness in soil $\mathrm{pH}$, an increase in the soil water retention capacity and enhancement in soil autochthonous microflora count. No remarkable changes in soil organic carbon and microbial biomass carbon were seen due to the low organic carbon content of treated waters. On the other hand the best germination indexes and growth levels for tested plant species were observed in the presence of treated wastewaters.

\section{Acknowledgements}

This work is carried out within the project CLARA (Capacity-linked water supply and sanitation improvement for Africa's peri-urban and rural Areas; Contract \# 265676; duration: 1.03.2011-28.02.2014), a collaborative project funded within the EU $7^{\text {th }}$ Framework Programme, theme "Environment (including Climate Change)". The CLARA team is grateful for the support.

\section{References}

[1] Jhansi, S.C. and Mishra, S.K. (2013) Wastewater Treatment and Reuse: Sustainability Options. Consilience: The Journal of Sustainable Development, 10, 1-15.

[2] Hamilton, A., Stagnitti, F., Xiong, X., Kreidl, S.L., Benke, K. and Maher, P. (2007) Wastewater Irrigation: The State of Play. Vadose Zone Journal, 6, 823-840. http://dx.doi.org/10.2136/vzj2007.0026

[3] Angin, I., Yaganoglu, A.V. and Turan, M. (2005) Effects of Long-Term Wastewater Irrigation on Soil Properties. Journal of Sustainable Agriculture, 26, 31-42. http://dx.doi.org/10.1300/J064v26n03_05

[4] WHO (2006) Wastewater Use in Agriculture. In: WHO Guidelines for the Safe Use of Wastewater, Excreta and Greywater, Vol. II, WHO, Geneva.

[5] Alloway, B.J. (1995) The Origin of Heavy Metals in Soils. In: Heavy Metals in Soils, Chapman \& Hall, London, 38-57. http://dx.doi.org/10.1007/978-94-011-1344-1_3

[6] McGrath, S.P. (1996) Effects of Heavy Metals from Sewage Sludge on Soil Microbes in Agricultural Ecosystems. In: Ross, S.M., Ed., Toxic Metals in Soil-Plants Systems, John Wiley \& Son, West Sussex, 247-274.

[7] Lazarova, V. and Asano, T. (2005) Challenges of Sustainable Irrigation with Recycled Water. In: Lazarova, V. and Bahri, A., Eds., Water Reuse for Irrigation, Agriculture, Landscapes and Turf Grass, CRC Press, London, New York, $1-30$.

[8] Mekki, A., Dhouib, A. and Sayadi, S. (2009) Evolution of Several Soil Properties Following Amendment with Olive Mill Wastewater. Progress in Natural Science, 19, 1515-1521. http://dx.doi.org/10.1016/j.pnsc.2009.04.014

[9] Anderson, T.H. (2003) Microbial Eco-Physiological Indicators to Assess Soil Quality. Agricultural Ecosystems. Environments, 98, 285-293.

[10] Keremane, G.B. and Mckay, J. (2008) Water Reuse Projects: The Role of Community Social Infrastructure. Water, 35, 35-39.

[11] Mekki, A., Dhouib, A. and Sayadi, S. (2006) Changes in Microbial and Soil Properties Following Amendment with Treated and Untreated Olive Mill Wastewater. Microbiological Research, 161, 93-101. http://dx.doi.org/10.1016/j.micres.2005.06.001

[12] Mohammad, M.J. and Mazahreh, N. (2003) Changes in Soil Fertility Parameters in Response to Irrigation of Forage Crops with Secondary Treated Waste Water. Communications in Soil Science and Plant Analysis, 34, 1281-1294. http://dx.doi.org/10.1081/CSS-120020444

[13] Russan, M.J.M., Hinnawi, S. and Rousan, L. (2007) Long Term Effect of Wastewater Irrigation of Forage Crops on Soil and Plant Quality Parameters. Desalination, 215, 143-152. http://dx.doi.org/10.1016/j.desal.2006.10.032

[14] Lado, M. and Ben-Hur, M. (2009) Treated Domestic Sewage Irrigation Effects on Soil Hydraulic Properties in Arid and Semiarid Zones: A Review. Soil and Tillage Research, 106, 152-163. http://dx.doi.org/10.1016/j.still.2009.04.011

[15] Sierra, J., Martí, E., Montserrat, G., Crauañas, R. and Garau, M.A. (2001) Characterization and Evolution of a Soil Affected by Olive Oil Mill Wastewater Disposal. Science of the Total Environment, 279, 207-214. http://dx.doi.org/10.1016/S0048-9697(01)00783-5

[16] Kjeldahl, J. (1883) Neue Methode zur Bestimmung des Stickstoffs in organischen Körpern [A New Method for the Determination of Nitrogen in Organic Matter]. Zeitschrift für Analytische Chemie, 22, 366-382.

http://dx.doi.org/10.1007/BF01338151 
[17] Knechtel, R.J. (1978) A More Economical Method for the Determination of Chemical Oxygen Demand. Journal of the Water Pollution Control Federation, May/June, 25-29.

[18] Kandeler, E. (1995) Total Nitrogen. In: Schinner, F., Ohlinger, R., Kandeler, E. and Margesin, R., Eds., Methods in Soil Biology, Springer, Berlin, 406-408.

[19] Yanko, W.A., Walker, A.S., Jackson, J.L., Libao, L.L. and Garcia, A.L. (1995) Enumerating Salmonella in Biosolids for Compliance with Pathogens Regulations. Water Environment Research, 67, 364-370. http://dx.doi.org/10.2175/106143095X131592

[20] Murray, P.R., Baron, E.J., Jorgensen, J.H., Pfaller, M.A. and Yolken, R.H. (2003) Manual of Clinical Microbiology. 8th Edition, American Society of Microbiology, Washington DC.

[21] Peredes, M.J., Moreno, E., Ramos-Cormenzana, A. and Martinez, J. (1987) Characteristics of Soil after Pollution with Waste Waters from Olive Oil Extraction Plants. Chemosphere, 16, 1557-1564. http://dx.doi.org/10.1016/0045-6535(87)90096-8

[22] Zucconi, F., Forte, M., Monac, A. and De Beritodi, M. (1981) Biological Evaluation of Compost Maturity. Biocycle, 22, 27-29.

[23] Al-Rashed, M.F. and Sherif, M.M. (2000) Water Resources in the GCC Countries: An Overview. Water Research Management, 14, 59-73.

[24] Qian, Y.L. and Mecham, B. (2005) Long-Term Effects of Recycled Wastewater Irrigation on Soil Chemical Properties on Golf Course Fairways. Agronomy Journal, 97, 717-721. http://dx.doi.org/10.2134/agronj2004.0140

[25] Lazarova, V. (1998) La réutilisation des eaux usées: Un enjeu de l'an 2000. L’Eau, L'Industrie, Les Nuisances, 212, 39-46.

[26] Pescod, M.B. (1992) Wastewater Treatment and Use in Agriculture. Irrigation and Drainage. Paper No. 47, FAO, 118.

[27] Bardgett, R.D. and Leemans, D.K. (1995) The Short-Term Effects of Cessation of Fertiliser Applications, Liming, and Grazing on Microbial Biomass and Activity in Reseeded Upland. Biology and Fertility of Soils, 19, 148-154. http://dx.doi.org/10.1007/BF00336151

[28] Schipper, L.A., Williamson, J.C., Kettles, H.A. and Speir, T.W. (1996) Impact of Land Applied Tertiary-Treated Effluent on Soil Biochemical Properties. Journal of Environment Quality, 25, 1073-1077. http://dx.doi.org/10.2134/jeq1996.00472425002500050020x

[29] Richards, T.L., Hamelers, H.V.M., Veeken, A. and Silva, T. (2002) Moisture Relationships in Composting Processes. Compost Science \& Utilization, 10, 286-302. http://dx.doi.org/10.1080/1065657X.2002.10702093

[30] Henin, S., Fies, J.C. and Monnier, G. (1970) Le profil cultural: L’état physique du sol et ses conséquences agronomiques. Masson et C.I.E., 128.

[31] Halilat, M.T., Dogar, M.A. and Adraoui, M. (1991) Effet de l'azote, du potassium et de leur interaction sur la nutrition du blé sur sol sableux du désert algérien. Revue Homme, Terre et Eaux, 30, 32-39.

[32] Jastrow, J.D. and Miller, R.M. (1991) Methods for Assessing the Effects of Biota on Soil Structure. Agriculture, Ecosystems \& Environment, 34, 279-303. http://dx.doi.org/10.1016/0167-8809(91)90115-E

[33] Sparling, G.P., Shepherd, T.C. and Kettles, H.A. (1992) Changes in Soil Organic C, Microbial C and Aggregates Stability under Continuous Maize and Cereal Cropping, and after Restoration to Pasture in Soils from the Manawatu Region, New Zealand. Soil and Tillage Research, 24, 225-241. http://dx.doi.org/10.1016/0167-1987(92)90089-T

[34] Siebe, C. (1998) Nutrient Inputs to Soils and Their Uptake by Alfalfa through Long-Term Irrigation with Untreated Sewage Effluent in Mexico. Soil Use and Management, 14, 119-122. http://dx.doi.org/10.1111/j.1475-2743.1998.tb00628.x

[35] Friedel, J.K., Langer, T., Siebe, C. and Stahr, K. (2000) Effects of Long-Term Waste Water Irrigation on Soil Organic Matter, Soil Microbial Biomass and Its Activities in Central Mexico. Biology and Fertility of Soils, 31, 414-421. http://dx.doi.org/10.1007/s003749900188

[36] Dexter, A.R. (1988) Advances in Characterization of Soil Structure. Soil and Tillage Research, 11, 199-238. http://dx.doi.org/10.1016/0167-1987(88)90002-5

[37] Piccolo, A., Pietramellara, G. and Mbagwu, J.S.C. (1997) Use of Humic Substances as Soil Conditioners to Increase Aggregate Stability. Geoderma, 75, 267-277. http://dx.doi.org/10.1016/S0016-7061(96)00092-4 